\title{
AITC inhibits fibroblast-myofibroblast transition via TRPA 1 -independent MAPK and NRF2/HO-1 pathways and reverses corticosteroids insensitivity in human lung fibroblasts
}

Jennifer Maries Go Yap ${ }^{1 \dagger}$, Takashi Ueda ${ }^{2 \dagger}$, Yoshihiro Kanemitsu ${ }^{1 *} \mathbb{0}$, Norihisa Takeda ${ }^{1}$, Kensuke Fukumitsu', Satoshi Fukuda', Takehiro Uemura ${ }^{1}$, Tomoko Tajiri ${ }^{1}$, Hirotsugu Ohkubo ${ }^{1}$, Ken Maeno ${ }^{1}$, Yutaka Ito ${ }^{1}$, Testsuya Oguri ${ }^{1}$, Shinya Ugawa ${ }^{2}$ and Akio Niimi ${ }^{1}$

\begin{abstract}
Background: Little is known on the role of transient receptor potential ankyrin 1 (TRPA1) in fibroblast-myofibroblast transition (FMT) that can lead to airway remodeling which is a major problem for severe asthma and fibrosis. Thus, this study investigated the effect of TRPA1 modulators on transforming growth factor beta 1(TGF- $\beta 1$ ) -treated lung fibroblasts.
\end{abstract}

Methods: MRC- 5 cells were preincubated with TGF- $\beta 1$ for $24 \mathrm{~h}$. TRPA 1 agonist or antagonist were added and further incubated for $24 \mathrm{~h}$. The changes in TRPA 1 and alpha-smooth muscle actin ( $\mathrm{a}-\mathrm{SMA}$ ) expressions by stimuli were evaluated using qRT-PCR, western blot and immunohistochemical analyses. Statistical significance was determined by using one- or two-way ANOVA, followed by Bonferroni's post hoc analysis for comparison of multiple groups and paired 2-tailed Student's t-test between 2 groups.

Results: MRC- 5 cells treated by TGF- $\beta 1$ significantly upregulated a-SMA mRNA expressions $(P<0.01)$, but downregulated TRPA1 gene expression ( $P<0.001)$. Post-treatment of TRPA1 activator, allyl isothiocyanate (AITC), after TGF- $\beta 1$ significantly downregulated the a-SMA gene induction $(P<0.01$ at $24 \mathrm{~h})$, protein expression $(P<0.05)$ and immunoreactivity with stress fibers $(P<0.05)$. On the other hand, TRPA1 antagonist HC-030031 did not prevent this effect, and instead tended to facilitate the suppressive effect of AITC when co-stimulated. AITC significantly increased phosphorylated- extracellular signal-regulated kinase (ERK) $1 / 2$ and heme oxygenase $(\mathrm{HO})-1$ protein expressions $(P<0.05)$ in TGF- $\beta 1$-treated cells. Combined inhibition with ERK1/2 mitogen-activated protein kinase (MAPK) and nuclear factor erythroid 2-related factor (NRF2) almost completely reversed AITC-induced a-SMA suppression $(P<0.05)$.

\footnotetext{
*Correspondence: kaney32@med.nagoya-cu.ac.jp

†Jennifer Maries Go Yap and Takashi Ueda contributed equally to this work

1 Department of Respiratory Medicine, Allergy and Clinical Immunology,

Nagoya City University Graduate School of Medical Sciences, 1 Kawasumi, Mizuho-cho, Mizuho-ku, Nagoya 467-8601, Japan

Full list of author information is available at the end of the article
}

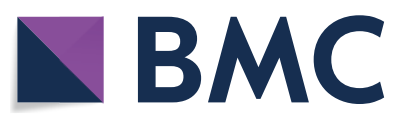

(c) The Author(s) 2021. Open Access This article is licensed under a Creative Commons Attribution 4.0 International License, which permits use, sharing, adaptation, distribution and reproduction in any medium or format, as long as you give appropriate credit to the original author(s) and the source, provide a link to the Creative Commons licence, and indicate if changes were made. The images or other third party material in this article are included in the article's Creative Commons licence, unless indicated otherwise in a credit line to the material. If material is not included in the article's Creative Commons licence and your intended use is not permitted by statutory regulation or exceeds the permitted use, you will need to obtain permission directly from the copyright holder. To view a copy of this licence, visit http://creativecommons.org/licenses/by/4.0/. The Creative Commons Public Domain Dedication waiver (http://creativeco mmons.org/publicdomain/zero/1.0/) applies to the data made available in this article, unless otherwise stated in a credit line to the data. 
Dexamethasone was not able to inhibit the upregulated a-SMA induction by TGF- $\beta 1$. However, AITC improved dexamethasone-insensitive myodifferentiation in the presence of the corticosteroid $(P<0.01)$.

Conclusion: We found that AITC exerts protective effect on TGF- $\beta 1$-induced $\alpha$-SMA induction by activating ERK1/2 MAPK and NRF2/HO-1 pathways in lung fibroblasts. It also overcomes corticosteroids insensitivity in TGF- $\beta 1$-induced a-SMA induction. TRPA1 antagonist modulates the suppressive effect, but not prevent it. AITC and TRPA1 antagonist may be therapeutic agents in treating chronic respiratory diseases.

Keywords: TRPA1, AITC, ERK1/2 MAPK pathway, NRF2/HO-1 pathway

\section{Background}

Chronic respiratory diseases such as asthma, chronic obstructive pulmonary disease (COPD), and idiopathic fibrosis (IPF) affect approximately 545 million in the world and account for 3.9 million deaths [1]. Although recommended management and treatment against these diseases were already stated in the guidelines [2-4], the unspecific and lack of treatments response among these patients $[5,6]$ suggest that there is a need for further understanding of the factors that underlie severity of these diseases.

Airway remodeling is strongly associated with the pathophysiology of asthma, COPD, and IPF [7-9]. Residing fibroblasts in the connective tissues of the bronchi are the most common source of myofibroblasts in which they transform their phenotype synthesizing extracellular matrix proteins and alpha-smooth muscle actin

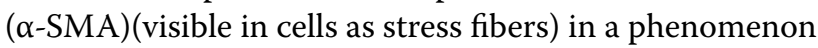
known as fibroblasts-to-myofibroblasts transition (FMT). Increased formation of myofibroblasts is observed in subepithelial remodeling in chronic respiratory diseases [10-12].

Transforming growth factor-beta (TGF- $\beta$ ) is an important FMT-inducing mediator [13] which also functions in regulating cell growth, morphogenesis, cell differentiation and apoptosis [14]. It facilitates pro-inflammatory responses and tissue remodeling in airways [15]. TGF- $\beta$ was also identified as the main cytokine that induces augmented matrix deposition mainly through fibroblast recruitment and transformation in the IPF lung [16]. TGF- $\beta$ can also stimulate and increase reactive oxygen species (ROS) production that leads oxidant and antioxidant imbalance which in turn can activate latent TGF- $\beta$ developing a profibrogenic cycle [17]. Moreover, TGF- $\beta 1$ is associated with corticosteroids insensitivity in chronic inflammatory diseases including asthma [18].

Transient receptor potential ankyrin 1 (TRPA1) is a major TRP channel in human lung fibroblasts. We have demonstrated that tumor necrosis factor- $\alpha$ (TNF- $\alpha$ ) can regulate airway inflammation by modulating TRPA1 expression on lung fibroblasts [19]. TRPA1 is activated by an antioxidant substance, allyl isothiocyanate (AITC), along with a variety of risk factors for respiratory diseases, such as cigarette smoke extract, bacterial endotoxins and painful cold. Activation of myofibroblast TRPA1 channel by corticosteroids and pirfenidone exerts its antifibrotic effects in intestinal fibrosis [20]. It is thus possible that TRPA1 is involved in development of FMT, oxidant and antioxidant imbalance, and corticosteroids sensitivity in lung fibroblasts during FMT. However, there are no studies exploring the involvement of TRPA1 in lung fibroblasts on airway remodeling and fibrosis. Thus, this study investigated the effect of TGF- $\beta$ on the expression of TRPA1 in lung fibroblasts. We also determine the response of fibroblasts stimulated by TGF- $\beta 1$ to TRPA1 agonist (AITC) and antagonist (HC-030031). We further explored the potential role of AITC in the pathogenesis of fibrosis that leads to airway remodeling.

\section{Materials and methods}

\section{Cell culture and treatment of cells}

MRC-5 and HF19 cells were provided by RIKEN BRC through the National Bio-Resource Project of the MEXT/ AMED, Japan (RCB021 and RCB0210) and were cultured in RITC80-7 medium supplemented with $10 \% \mathrm{FCS}$, penicillin, and streptomycin in $37{ }^{\circ} \mathrm{C}$ with $5 \% \mathrm{CO}_{2}$. Cells were seeded in 6-well plate for qRT-PCR and protein expressions and in 4-chamber slides for immunostainings using 1\% FBS RITC80-7 medium. Time-point experiments were done at 24,48 , and $72 \mathrm{~h}$ after TGF- $\beta 1$ treatment $(5 \mathrm{ng} / \mathrm{mL})$ and confirmed that $24 \mathrm{~h}$ treatment with TGF$\beta 1$ already upregulated gene expressions of $\alpha$-SMA and collagen type 1 alpha 1 chain (Col1A1) (Additional file 1: Figure S1). Cells were initially incubated with TGF- $\beta 1$ $(5 \mathrm{ng} / \mathrm{mL})$ for $24 \mathrm{~h}$ to induce FMT. The TGF- $\beta 1$ - treated cells were then stimulated with $\mathrm{HC}-030031(10 \mu \mathrm{M})$ or AITC $(10 \mu \mathrm{M})$ and were incubated further for $24 \mathrm{~h}$ in the presence of TGF- $\beta 1$. Cells were incubated for a total of $48 \mathrm{~h}$ before harvest.

\section{RNA Isolation and CDNA synthesis}

Total RNA was isolated using ISOGEN reagent according to manufacturer's protocol (Fujifilm Wako, Osaka, Japan). cDNA was synthesized using the Superscript IV VILO Master Mix with ezDNase kit following the manufacturer's protocol (Invitrogen by Thermo Fisher Scientific, 
USA). Total RNA concentration of $1500 \mathrm{ng}$ was used to synthesize cDNA.

\section{Quantitative RT-PCR of Target Genes}

Quantitative RT-PCR of target genes were analyzed using 7900 HT Fast real time PCR system (Applied biosystems Thermo Fisher Scientific, USA). We established specific primers as described previously (Additional file 1: Table S1) [19]. Relative gene expressions were calculated using $2^{-\Delta \Delta \mathrm{Ct}}$ method after normalized with $\beta$-actin.

\section{Immunostaining}

MRC- 5 cells mounted on slides were air dried for $10 \mathrm{~min}$ and fixed in $4 \%$ paraformaldehyde for $15 \mathrm{~min}$. Slides were then blocked with $5 \%$ normal donkey serum in phosphate buffered saline (PBS) containing $0.3 \%$ Triton X-100 for $30 \mathrm{~min}$ and were incubated overnight with $\alpha$-SMA antibody (Table 1 ) at $4{ }^{\circ} \mathrm{C}$. Cells were then washed with PBS and incubated with anti-mouse Alexa 488 secondary antibody for $1 \mathrm{hr}$. Immunostained cells were observed and analyzed under NIKON A1RS + confocal microscope (NIKON, Japan).

\section{Western blot analysis}

Western blot analysis was performed as described previously [19], except for loaded protein volume $(10 \mu \mathrm{g})$. Membranes were incubated with anti-GAPDH [4967S, Cell Signaling Technology (CST), Japan] or primary antibodies (Table 1) and followed by anti-rabbit IgG HRPconjugated antibody (7074S, CST) and/or anti-mouse IgG HRP-conjugated antibody (W402B, Promega, USA). The bands were detected using chemiluminescence kit
(ECL detection system; GE healthcare, USA) and were quantified using Image J software.

\section{Wound healing assay}

MRC- 5 cells were starved for $12 \mathrm{~h}$ in serum free medium and were grown to $80 \%$ confluence in 6-well plates. They were scratched by a $200 \mu \mathrm{L}$ pipette tip to create gaps with uniform size. Cells were then washed twice with PBS to remove floating cells and were exposed in the presence of absence of $5 \mathrm{ng} / \mathrm{mL}$ TGF- $\beta 1$. Cells were also treated with or without $10 \mu \mathrm{M}$ AITC and/or $10 \mu \mathrm{M}$ HC-030031 in serum free medium for $24 \mathrm{~h}$. The number of migrating cells in the gap were counted in three fields from each treatment under a light microscope.

\section{Statistical analysis}

Data were represented as means \pm SEM and were analyzed using GraphPad Prism 5 statistical software. Statistical significance was determined by using one- or two-way ANOVA, followed by Bonferroni's post hoc analysis for comparison of multiple groups and the paired 2-tailed Student's t-test between 2 groups. $P<0.05$ was considered statistically significant.

\section{Results}

TGF- $\beta 1$ upregulated remodeling related genes expressions and downregulated TRPA 1 gene expression

First, we investigated the effect of TGF- $\beta 1$ on expressions of remodeling related genes such as $\alpha$-SMA, Col1A1, tissue inhibitor matrix metalloproteinase 1 (TIMP1), periostin, and matrix metalloprotease 9 (MMP9) by using qRT-PCR. Treatment of MRC- 5 cells with different concentrations of TGF- $\beta 1$ ( 1 and $5 \mathrm{ng} / \mathrm{mL}$ ) for $24 \mathrm{~h}$

Table 1 List of antibodies used for western blot analysis

\begin{tabular}{|c|c|c|c|}
\hline Primary and Secondary antibodies & & Size (kDa) & Code \\
\hline a-SMA & $\begin{array}{l}\text { Monoclonal mouse anti-human } \\
\text { smooth muscle actin, clone 1A4 }\end{array}$ & 43 & M0851, DAKP/Agilent \\
\hline GAPDH & D16H11 XP Rabbit mAb & 37 & 5174, Cell Signaling Technology, MA, USA \\
\hline $\mathrm{Smad} 2 / 3$ & D7G7 XP Rabbit mAb & 52,60 & 8685, Cell Signaling Technology, MA, USA \\
\hline Smad 2 & D43B4 XP Rabbit mAb & 60 & 5339, Cell Signaling Technology, MA, USA \\
\hline Smad 3 & C67H9 Rabbit mAb & 52 & 9523, Cell Signaling Technology, MA, USA \\
\hline Phospho-Smad 2 (Ser465/467) & 138D4 Rabbit mAb & 60 & 3108, Cell Signaling Technology, MA, USA \\
\hline Phospho-Smad 3 (Ser423/425) & C25A9 Rabbit mAb & 52 & 9520, Cell Signaling Technology, MA, USA \\
\hline ERK1/2 (p44/42) MAPK & 137F5 Rabbit mAb & 46,54 & 4695, Cell Signaling Technology, MA, USA \\
\hline p38 MAPK & D13E1 XP Rabbit mAb & 40 & 8690, Cell Signaling Technology, MA, USA \\
\hline SAPK/JNK & Rabbit Ab & 46,54 & 9252, Cell Signaling Technology, MA, USA \\
\hline Phospho-ERK1/2 (p44/42) MAPK (Thr202/Tyr204) & D13.14.4E XP Rabbit mAb & 42,44 & 4370, Cell Signaling Technology, MA, USA \\
\hline Phospho-p38 MAPK (Thr180/Tyr182) & D3F9 Xp Rabbit mAb & 40 & 4511, Cell Signaling Technology, MA, USA \\
\hline Phospho-SAPK/JNK (Thr 183/Tyr 185) & 81E11 Rabbit mAb & 46,54 & 4668, Cell Signaling Technology, MA, USA \\
\hline $\mathrm{HO}-1$ & E3F4S Rabbit mAb & 28 & 43,966, Cell Signaling Technology, MA, USA \\
\hline
\end{tabular}


significantly upregulated the gene expressions of $\alpha$-SMA $(P<0.05)$, and was prone to increase gene expression of Col1A1 and periostin (Fig. 1a). We also confirmed the TGF- $\beta 1$-induced FMT in HF19 another human lung fibroblast cell line (Fig. 1b). These support the previous finding that TGF- $\beta 1$ promotes FMT in lung fibroblasts [7].

Recently, we reported that TRPA1 gene expression was upregulated upon treatment with TNF- $\alpha$, another mediator for airway inflammation in chronic respiratory diseases [19]. Therefore, we also evaluated the effect of TGF- $\beta 1$ on the gene expressions of TRPA1 in lung fibroblasts. Contrary to TNF- $\alpha$ treatment, MRC- 5 cells treated with TGF- $\beta 1$ significantly downregulated TRPA1 gene expressions $(P<0.05)$ (Fig. 1a). We also checked the gene expression in HF19 cells and obtained similar results (Fig. 1b). Unlike TNF- $\alpha$, TGF- $\beta 1$ could negatively regulate TRPA1 gene expression during the process of FMT in lung fibroblasts.

\section{AITC suppressed TGF- $\beta 1$-induced $\alpha$-SMA expression and cell migration in lung fibroblasts}

To examine the role of TRPA1 channel in FMT induced by TGF- $\beta 1$ in lung fibroblasts, we used allyl isothiocyanate (AITC), a pungent chemical that is an ingredient of wasabi and mustard oil and is well known activator of the TRP channel, and HC-030031, a selective TRPA1 antagonist. MRC- 5 cells were treated with AITC or HC-030031 for $24 \mathrm{~h}$ after TGF- $\beta 1$ application. RNA samples were collected at $48 \mathrm{~h}$ after TGF- $\beta 1$ for qRT-PCR analysis.
We found that HC-030031 failed to reduce TGF- $\beta 1$ induced $\alpha$-SMA, collagen, and periostin gene expressions (Fig. 2a). In contrast, AITC significantly downregulated TGF- $\beta 1$-induced $\alpha$-SMA gene expression even in delayed application $(P<0.01$ at $24 \mathrm{~h})$ (Fig. 2b).

TGF- $\beta 1$ induces $\alpha$-SMA protein expression with stress fibers, a feature of myofibroblasts in process of FMT [21]. Treatment of MRC- 5 cells with $5 \mathrm{ng} / \mathrm{mL}$ TGF- $\beta 1$ for $48 \mathrm{~h}$ was sufficient to induce upregulation of $\alpha$-SMA protein (Fig. 3a). Treatment with $10 \mu \mathrm{M}$ AITC for $24 \mathrm{~h}$ after TGF$\beta 1$ significantly inhibited the upregulated $\alpha$-SMA protein expression $(P<0.05)$. However, the suppressive effect of AITC was not reversed by simultaneous administration of $10 \mu \mathrm{M}$ HC-030031. Instead, the TRPA1 antagonist tended to decrease the exacerbated $\alpha$-SMA protein expression when stimulated together with AITC (Fig. 3a). We also observed immunohistochemical changes of $\alpha$-SMA proteins after TGF- $\beta 1$ in the presence or absence of AITC under a confocal laser scanning microscope (Fig. 3b). TGF- $\beta 1$ significantly increased $\alpha$-SMA-positive cells with stress fibers (Fig. $3 \mathrm{~b} ; \mathrm{b}$ and e, $P<0.01$ ), which were suppressed prominently by co-treatment with AITC (Fig. 3b; c and e, $P<0.05$ ). However, HC-030031 failed to counteract the suppressive effect of AITC (Fig. 3b, d and e).

We also examined the effect of AITC on cell migration because TGF- $\beta 1$ is also known to activate cell migration [22] (Fig. 4). There was no significant difference between control (Fig. 4a) and AITC (Fig. 4b) or HC-030031 alone (Fig. 4c). As compared to control, TGF- $\beta 1$ activated cell
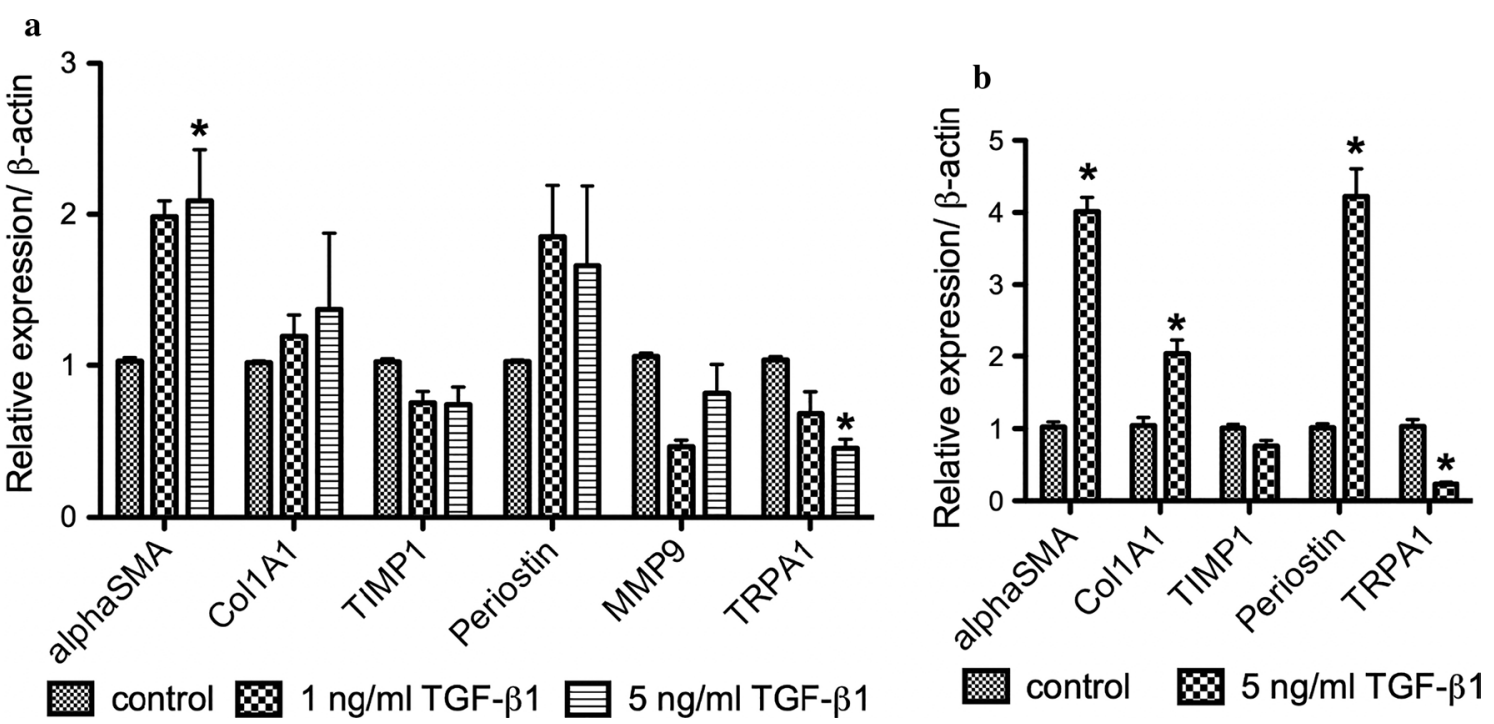

Fig. 1 Relative gene expressions of TRP channels and remodeling gene markers after TGF- $\beta 1$ stimulation in lung fibroblasts. MRC-5 cells (a) and HF19 cells (b) were treated with different concentrations (1 or $5 \mathrm{ng} / \mathrm{mL}$ ) of TGF- $\beta 1$. Gene expressions of TRP channels and remodeling gene markers were determined by qRT-PCR. $\beta$-actin was used to normalize the expressions. ${ }^{*} P<0.05$ compared with the respective control). $\mathrm{N}=4$ 

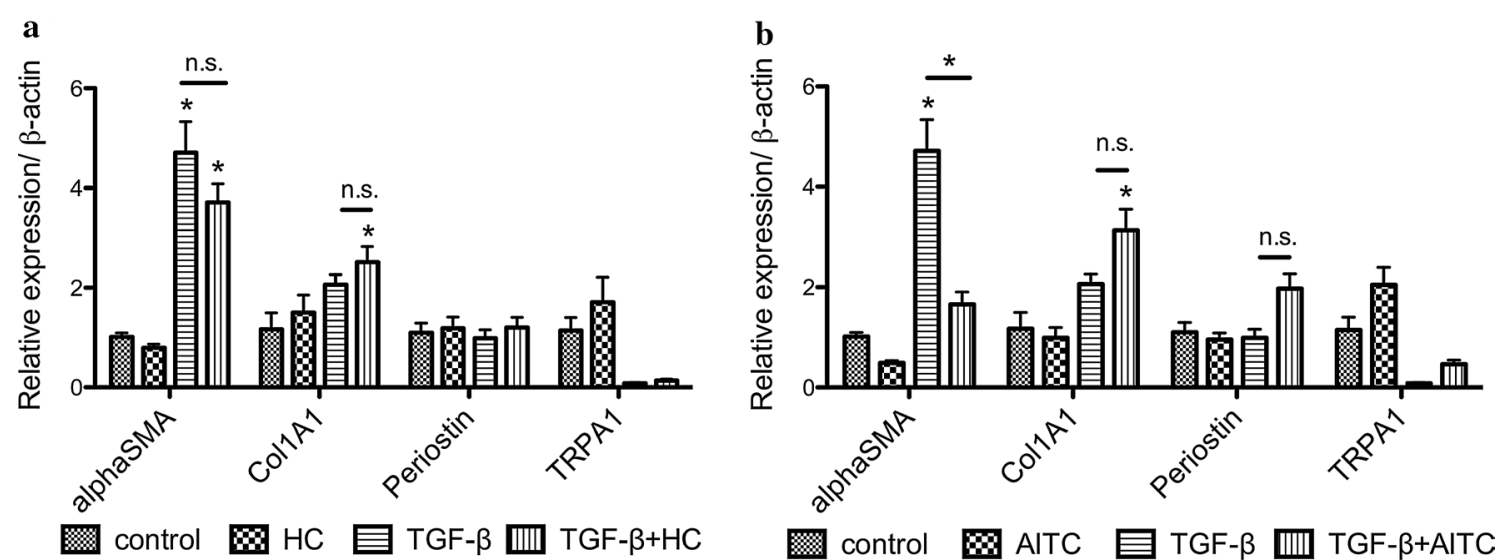

Fig. 2 Effect of AITC and selective TRPA1 antagonist HC-030031 on remodeling gene markers after TGF- $\beta 1$ stimulation. a MRC-5 cells were incubated with TGF- $\beta 1$ ( $5 \mathrm{ng} / \mathrm{mL})$ for $24 \mathrm{~h}$ and then treated with HC-030031 (30 $\mu \mathrm{M})$ for $24 \mathrm{~h}$ (TGF- $\beta+\mathrm{HC})$ in the presence of TGF- $\beta 1$. TGF- $\beta 1$ significantly increased $a-S M A$ gene expression $(* P<0.05)$ and were not inhibited by HC-030031. $N=3$. b MRC-5 cells were incubated with TGF- $\beta 1$ ( $5 \mathrm{ng} / \mathrm{mL})$ for $24 \mathrm{~h}$ and then treated with AITC $(30 \mu \mathrm{M})$ for $24 \mathrm{~h}$ (TGF- $\beta$ + AITC) in the presence of TGF- $\beta 1$. The TGF- $\beta 1$-induced a-SMA was significantly inhibited by AITC ( ${ }^{*} P<0.01,{ }^{*}$ without bar means the results when compared with the respective control). $N=3$

migration (Fig. 4d and h). AITC significantly inhibited the migration of TGF- $\beta 1$-treated MRC-5 cells $(P<0.001)$ (Fig. 4e and h). Exposure of HC-030031 to TGF- $\beta 1$ treated cells did not hinder the migration of cells (Fig. 4f) and was not able to reverse the suppressive effect of AITC (Fig. 4g).

We performed calcium imaging analysis whether AITC could induce calcium response in lung fibroblasts after treatment of TGF- $\beta 1$ for $24 \mathrm{~h}$ and HC-030031 could inhibit it. AITC exhibited significant calcium influx with $\mathrm{EC}_{50}$ of 2.7-3.6 $\mu \mathrm{M}$ comparable to untreated in the fibroblasts treated with TGF- $\beta 1$. Moreover, the calcium response was significantly inhibited by HC-030031, a selective TRPA1 antagonist (Additional file 1: Figure S2). Signifying the presence of TRPA1 independent pathway to inhibit TGF- $\beta 1$-induced FMT by AITC.

\section{AITC activated ERK MAPK pathway independent}

\section{of Smad2/3 pathway during TGF- $\beta 1$-induced lung FMT}

Smad2/3 phosphorylation could be prominent in early stage after TGF- $\beta 1$ stimulation [23]. Therefore, we determined if the suppressive effect of AITC may be regulated by Smad 2 or Smad 3 pathway. We examined the effect of AITC on Smad2/3 phosphorylation in MRC-5 fibroblasts incubated with AITC for $1 \mathrm{hr}$ after preincubation with TGF- $\beta 1$. TGF- $\beta 1$ apparently phosphorylated Smad 2 and Smad 3 as seen in the upregulation $(P<0.001)$, but AITC or $\mathrm{HC}-030031$ did not affect $\mathrm{Smad} 2 / 3$ phosphorylation (Fig. 5a).

We next checked for non-Smad signaling pathways of TGF- $\beta 1$. Mitogen-activated protein kinase (MAPK) signaling pathways have also been associated with development or inhibition of fibrotic responses through propagating signals initiated by growth factors such as TGF- $\beta 1[24,25]$. Delayed application of AITC $24 \mathrm{~h}$ after TGF- $\beta 1$ notably induced phosphorylation of ERK1/2 in MRC- 5 cells treated with TGF- $\beta 1$ at $48 \mathrm{~h}$ (Fig. $5 \mathrm{~b}$ ). Treatment with HC-030031 did not affect ERK1/2 phosphorylation. In contrast, no phosphorylated JNK and p38 were detected in the present study (data not shown). To check the possible contribution of ERK $1 / 2$ in the suppression of TGF- $\beta 1$-induced $\alpha$-SMA by AITC, we utilized U0126, an ERK inhibitor. The inhibitor slightly upregulated TGF$\beta 1$-induced $\alpha$-SMA, supporting the finding that ERK inhibition further promoted FMT [24, 25]. AITC significantly reversed the aggravated effect of ERK inhibition on TGF- $\beta 1$ induced $\alpha$-SMA expression (Fig. 5 c). Collectively, ERK1/2 MAPK pathway, but not Smad pathway, could contribute to the suppression of TGF- $\beta 1$-induced FMT by AITC.

\section{AITC remarkably increased HO-1 protein expression through activation of ERK MAPK pathway}

Previous studies have demonstrated the protective role of heme oxygenase-1 (HO-1) on tissue remodeling [2629]. We next determined the protein expression levels of HO- 1 in TGF- $\beta 1$-treated MRC-5 cells incubated with AITC or HC-030031. TGF- $\beta 1$ triggered oxidant and antioxidant imbalance by inhibiting $\mathrm{HO}-1$ protein expression (Fig. 6a). Exposure with AITC significantly enhanced protein expressions of $\mathrm{HO}-1$ in TGF- $\beta 1$-treated MRC-5 cells, whereas HC-030031 with AITC did not have any changes (Fig. 6a). Increased expression of HO-1 by AITC was inhibited by ERK inhibitor, U0126 (Fig. 6b). Thus, 

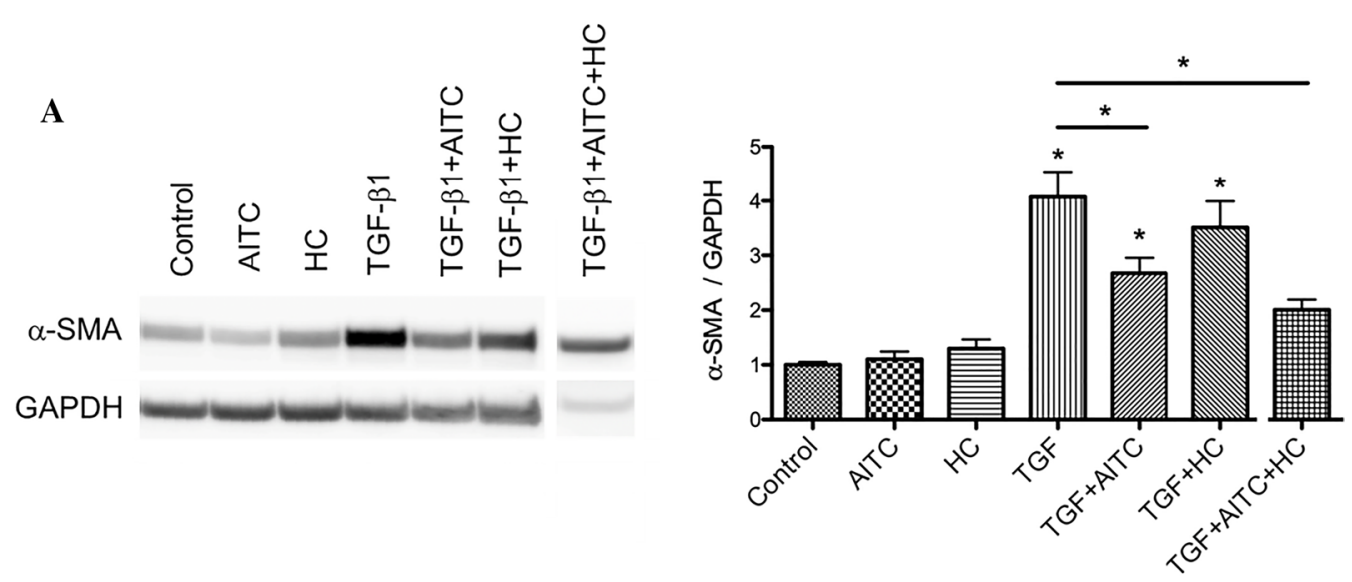

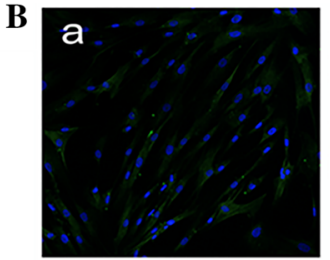

Control

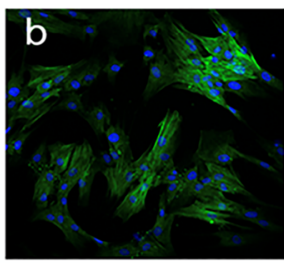

TGF- $\beta 1$

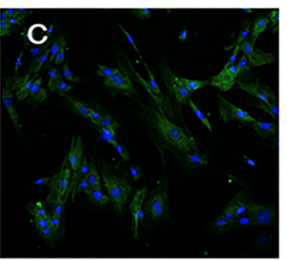

TGF- $\beta 1+A I T C$

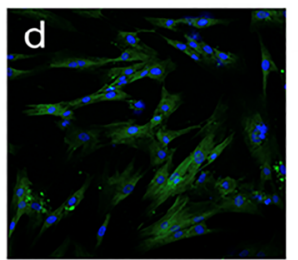

TGF- $\beta 1+\mathrm{AITC}+\mathrm{HC}$

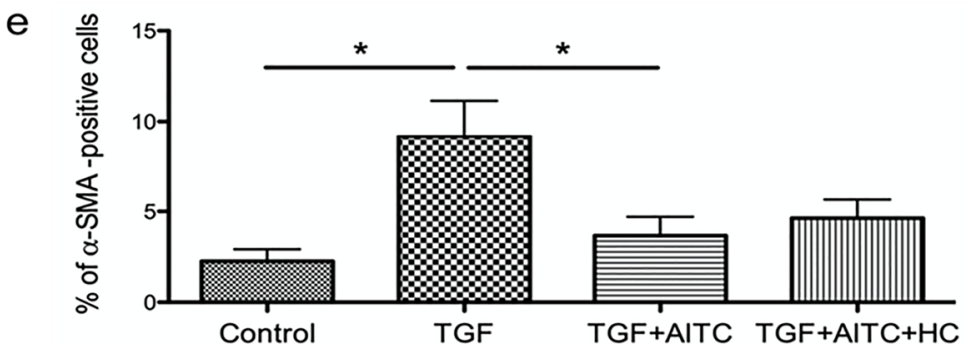

Fig. 3 Effect of TRPA1 modulators on protein expression and immunoreactivity of a-SMA after TGF- $\beta 1$ stimulation. a Western blot analysis of a-SMA protein expression after treatment with AITC $(10 \mu \mathrm{M})$, HC-030031 $(10 \mu \mathrm{M})$ or AITC $(10 \mu \mathrm{M})+\mathrm{HC}-030031(10 \mu \mathrm{M})$ for $24 \mathrm{~h}$ in the latter with TGF- $\beta 1$ incubation for $48 \mathrm{~h}$ where TGF- $\beta 1$-induced $\mathrm{a}$-SMA protein expression was decreased by AITC ( ${ }^{*} P<0.05$ at TGF vs TGF + AITC or TGF + AITC + HC). $\mathrm{N}=5$. $\mathbf{b}$ Immunohistochemical results showing a-SMA protein expression with stress fibers in cells after similar treatment to (a). (e) Summary of quantification of $a-S M A$ positive cells. TGF- $\beta 1$ increased a-SMA-immunoreactive cells and AITC significantly reduced number of the positive cells $\left({ }^{*} P<0.05,{ }^{*}\right.$ without bar; compared with control). $N=6$

AITC could suppress TGF- $\beta 1$-induced FMT by activating HO-1 and ERK1/2 MAPK pathways.

\section{AITC may activate antioxidant Nrf2/HO-1 pathway}

We further examined the involvement of NRF2 signaling using NRF2 inhibitor, ML-385, since it is well known to modulate HO- 1 expression. TGF- $\beta 1$-treated MRC-5 cells were incubated with ML-385 and/ or AITC for $24 \mathrm{~h}$ before harvesting protein for western blot analysis. Incubation with ML-385 showed no apparent reversal effect on AITC-induced $\alpha$-SMA suppression in TGF- $\beta 1$-treated cells (Fig. 6c), though it reduced HO-1 protein expression (data not shown). There is no significant difference between TGF + AITC and TGF + ML385 + AITC, although NRF2 inhibition tended to partially cancel AITC- induced $\alpha$-SMA inhibition (Fig. 6c). Finally, application of both NRF2 and ERK inhibitors significantly reversed AITC-induced protective effect to TGF- $\beta 1$ induced $\alpha$-SMA induction (Fig. $6 \mathrm{c}$ ). AITC could activate both ERK1/2 MAPK and NRF2/HO-1 pathways in suppressing TGF- $\beta 1$-induced expression of $\alpha$-SMA.

\section{AITC significantly improved dexamethasone insensitivity} Generally, TGF- $\beta 1$ impairs corticosteroid action. Corticosteroids were not effective in modulating fibrotic processes that leads to remodeling [23, 30-32]. To confirm this phenomenon, we treated MRC-5 cells with either TGF- $\beta 1$ or IL-4/IL-13 and incubated with 

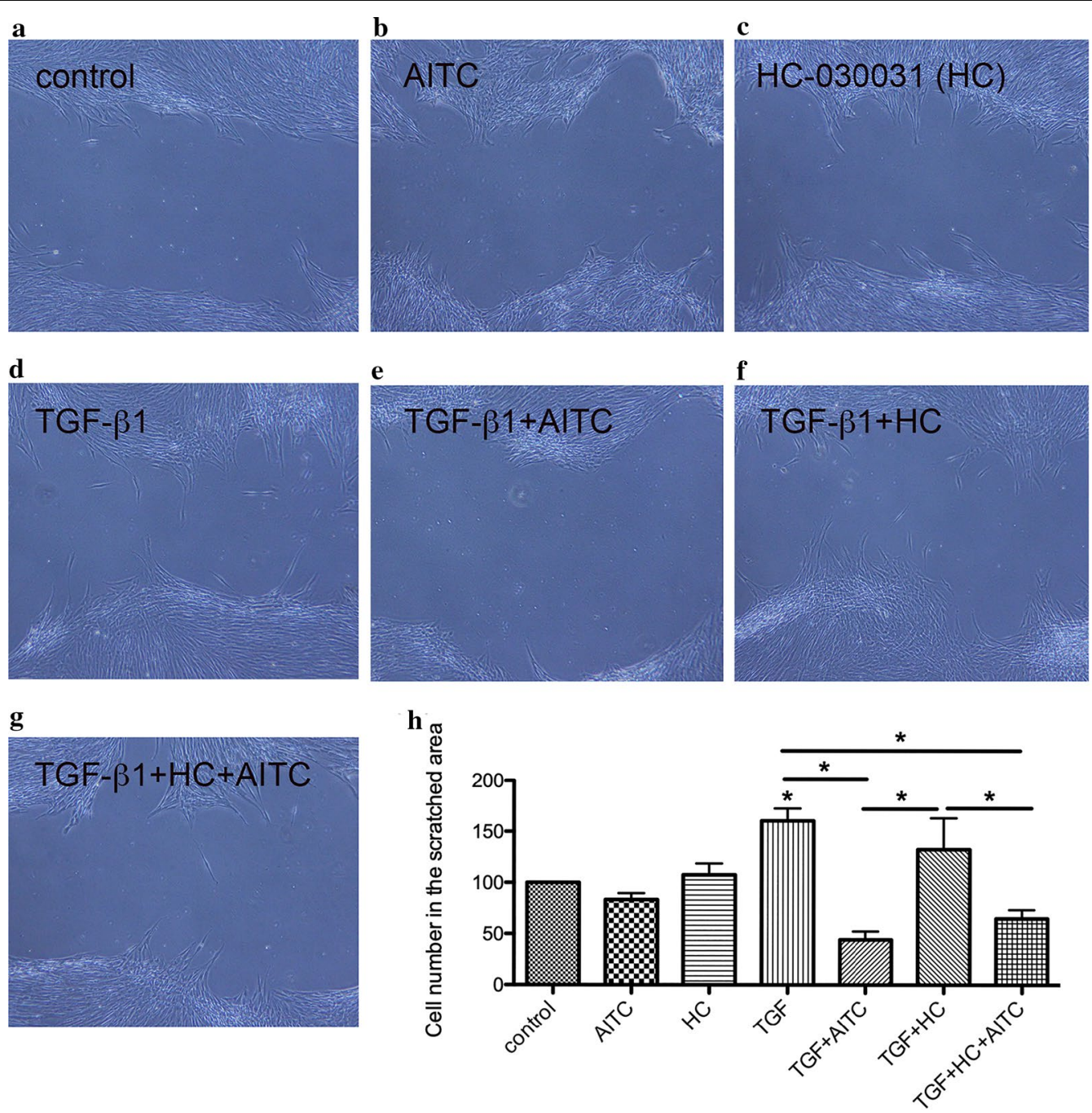

Fig. 4 Effect of AITC and selective TRPA1 antagonist HC-030031 on cell migration after TGF- $\beta 1$ stimulation. a-g Representative images under light microscope and $\mathbf{h}$ quantification of cell number in the gap area. Cells were manually scratched with a pipette tip, incubated with $\mathbf{b}$ AITC alone or c HC-030031 alone, and pretreated with d TGF- $\beta 1(5 \mathrm{ng} / \mathrm{ml})$ and incubated with e AITC $(10 \mu \mathrm{M})$ or $\mathbf{f}$ HC-030031 $(10 \mu \mathrm{M})$ or $\mathbf{g}$ AITC $(10 \mu \mathrm{M})+\mathrm{HC}-030031(10 \mu \mathrm{M})$ for $24 \mathrm{~h}$. TGF- $\beta 1$ promoted migration of MRC- 5 cells and AlTC significantly inhibited the migration of TGF- $\beta 1$-treated MRC-5 cells. HC-030031 did not hinder the migration of cells and was not able to reverse the suppressive effect of AITC $\left({ }^{*} P<0.05\right)$. N $=7$

dexamethasone. Figure 7a showed that IL-4/IL-13 treatment increased periostin mRNA levels $(P<0.0001)$ and the upregulated expression was significantly blocked by dexamethasone $(P<0.01)$. In contrast, TGF- $\beta 1$-induced gene expressions of $\alpha$-SMA and periostin were not blocked and was further exaggerated by dexamethasone (Fig. 7a), reflecting refractoriness to corticosteroids against TGF- $\beta 1$-induced airway inflammation. Upon confirming refractoriness to corticosteroids, we determined the effect of AITC on this phenomenon. Indeed, AITC significantly inhibited TGF- $\beta 1$ - and dexamethasone- induced protein expression of $\alpha$-SMA $(P<0.01)$ (Fig. 7b), suggesting that AITC recovers response to corticosteroids against TGF- $\beta 1$-induced airway inflammation.

\section{Discussion}

The present study demonstrated a possible role of TRPA1 and its modulators on FMT, an indicator of airway remodeling in human lung fibroblasts. First, we showed for the first time the anti-remodeling effect of TRPA1 activator AITC in lung fibroblast by suppressing TGF$\beta 1$-induced $\alpha$-SMA gene and protein expressions as well as impeding cell migration and reducing stress fiber formation. Second, this suppressive effect was mediated through ERK1/2 MAPK and NRF2/HO-1 antioxidant 

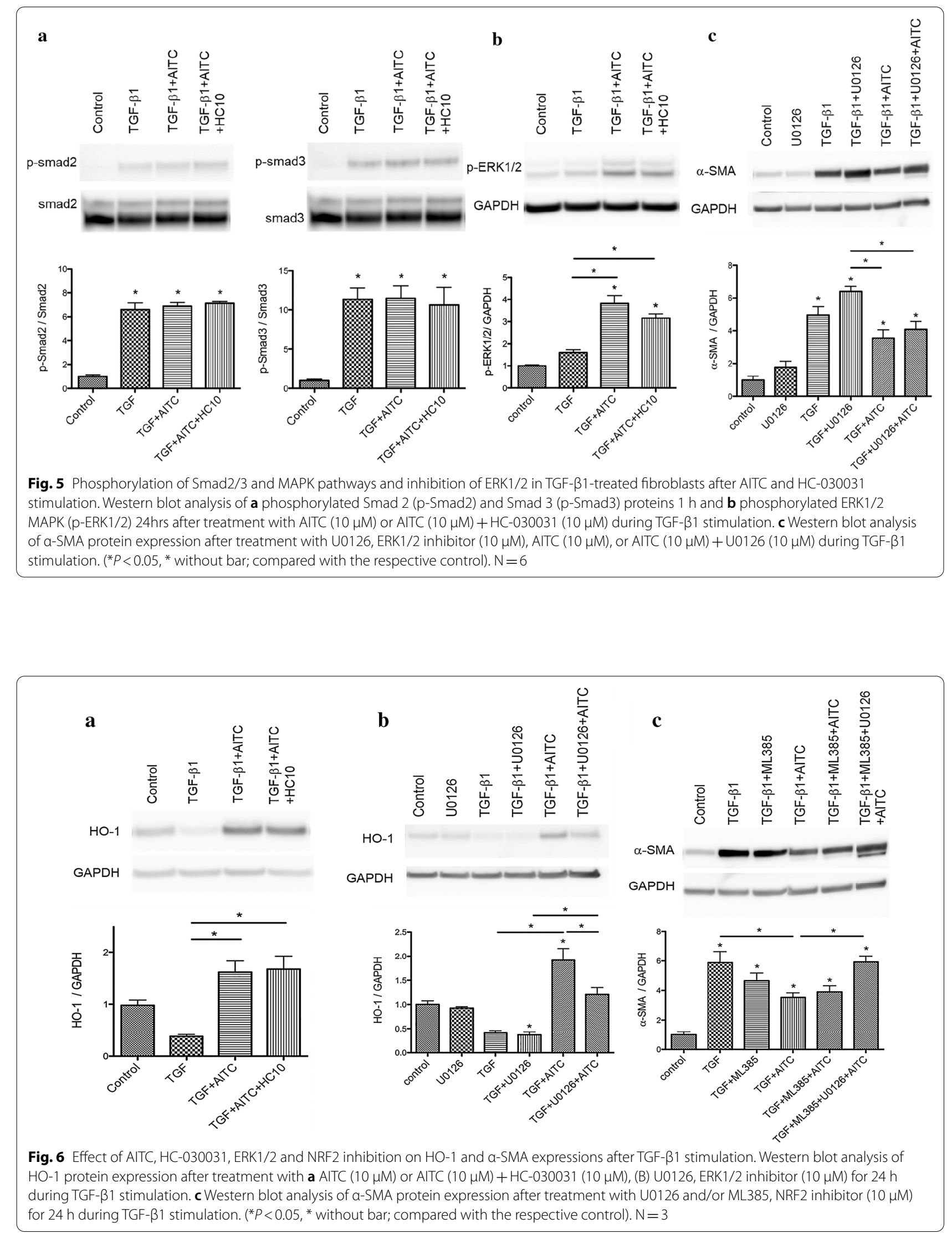


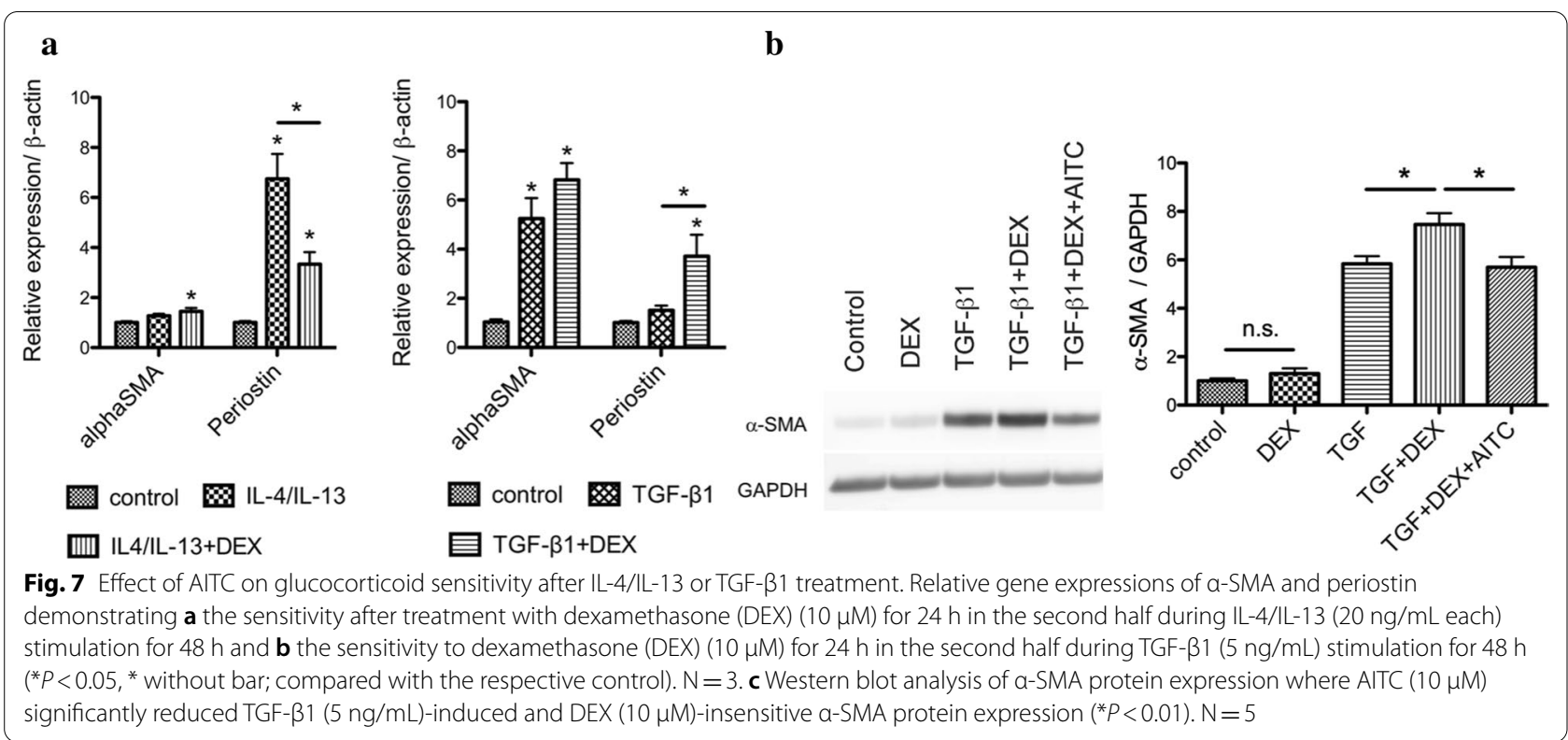

pathway. Third, TRPA1 antagonist do not hinder the effect of AITC instead tends to facilitate it. Finally, AITC also has the capacity to inhibit the upregulated $\alpha$-SMA expression resistant to dexamethasone in the presence of corticosteroids. The possible application of both TRPA1 modulators may be applicable for alleviating airway remodeling and airway hypersensitivity in chronic respiratory diseases.

Our study indicated that AITC suppresses TGF$\beta 1$-induced $\alpha$-SMA expression in TRPA1-independet mechanism. This result was in congruent with the recent finding that blockade of TRPA1 by A967079, another selective TRPA1 inhibitor, did not reduce myofibroblast contraction, changes in $\alpha$-SMA stress fibers, nor FBS-induced wound healing [33, 34]. In contrast, our calcium imaging analysis confirmed that AITC actually induced calcium response in lung fibroblasts treated with TGF- $\beta 1$ for $24 \mathrm{~h}$ and HC-030031 significantly blocked it. Note that HC-030031 tended to downregulate TGF- $\beta 1$-induced $\alpha$-SMA protein expression when co-treated with AITC (Fig. 3a). These suggest that TRPA1 channel is still functional and may have a role during early phase of FMT. Myofibroblasts express abundant inflammatory mediators, cytokines and growth factors such as TGF- $\beta$, granulocyte-macrophage colonystimulating factor (GM-CSF), interleukins (IL-1, IL-6, IL-8) and vascular endothelial growth factor (VEGF) [7]. We previously reported that TRPA1 channel was involved in excessive IL- 8 release in TNF- $\alpha$-stimulated MRC-5 cells [19]. We should examine the role of TRPA1 on cytokine release during FMT in future study. Thus, there could be more mechanisms present that are either
TRPA1-dependent or independent which synergistically contribute to the phenomenon found in lung fibroblasts during FMT. Further studies are needed to elucidate this effect of TRPA1 antagonist on FMT.

Previous studies reported that AITC acted through TRPA1 [35-37], but there are some reports describing TRPA1-independent AITC effect as well [38-40]. We determined that AITC could suppress FMT induced by TGF- $\beta 1$ through the activation of ERK1/2 MAPK and HO-1/NRF pathways in TRPA1-independent manner. The suppressive effect of AITC was insensitive to HC-030031, whereas it was reversed by co-treatment with ERK1/2 inhibitor, U0126 and NRF2 inhibitor, ML385. These findings are in line with the previous reports, in which AITC enhanced phosphorylation of ERK and induced antioxidant enzymes such as NAD(P) $\mathrm{H}$ dehydrogenase [quinone] 1 (NOQ1), HO-1, NRF2 and $\gamma$-glutamylcysteine synthetase $(\gamma \mathrm{GCS})$ in NIH3T3 mouse dermal fibroblasts [41] and cigarette smoke extract (CSE)-exposed 16HBE human bronchial epithelial cells [42]. Activating NRF2 attenuated both OVA-induced allergic airway inflammation and bleomycin-induced pulmonary fibrosis in rodents $[43,44]$. The present finding that AITC targets the NRF2/HO-1 pathway to reduce FMT in human lung fibroblasts could be of value as potential therapeutic strategy for treatment of chronic respiratory disease.

As previously reported, patients with severe asthma are less responsive to corticosteroids than those with mild asthma and consequently considered that corticosteroids resistance might be a mechanism contributing to asthma severity $[45,46]$. As well as patients 
suffering from IPF and COPD were also initially prescribed with corticosteroids and showed no response to corticosteroid therapy $[47,48]$. We also found that AITC was able to reverse the action of dexamethasone, which failed to inhibit TGF- $\beta 1$-induced $\alpha$-SMA proteins in lung fibroblasts (Fig. 7b). Recent studies demonstrated that the isothiocyanate sulforaphane (SFN) reversed corticosteroid resistance by modulating NRF2 pathway in cigarette smoke-exposed asthmatic mice [49] and in a mixed granulocyte mouse model of asthma [50]. AITC is known to be a structurally related compound of SFN and has a similar effect in activating NRF2/HO-1 pathway $[41,42]$. Thus, it may be possible that AITC treatment could restore corticosteroids sensitivity by activating NRF2/HO-1 pathway in human lung fibroblasts. However, additional investigations are needed, since previous studies utilized different cells from lung fibroblasts and mouse models, in which AITC equally acts on a variety of non-specific cells such as epithelial and immune cells present.

This study has several limitations. First, mechanisms involving TRPA1 dependent and independent remains to be elucidated as this study was done in a single cell line only. We would like to further understand these mechanisms utilizing samples from patients suffering from chronic respiratory diseases. Second, the experimental conditions were limited to certain concentrations and time exposure which can only mimic certain level of fibrosis in cells. Third, $\alpha$-SMA was the only marker investigated as it was the most reactive among tested. Further experimentations including other markers of airway remodeling and cytokine release would be needed to further verify the role of TRPA1 in human lung fibroblasts. Fourth, we should determine the molecular mechanisms involved in restoring corticosteroids sensitivity of AITC, as several molecular mechanisms that might be responsible for reduced corticosteroids [51, 52]. Fifth, utilizing experimental animal models are recommended for verification of the anti-remodeling effect of AITC.

\section{Conclusion}

The present study reported for the first time that AITC suppressed TGF- $\beta 1$ induced gene and protein expression of $\alpha$-SMA through induction of HO-1 via ERK $1 / 2$ MAPK and NRF2 pathways. AITC also inhibited TGF$\beta 1$-induced and dexamethasone-insensitive $\alpha$-SMA expression and may reverse corticosteroids resistance in lung fibroblasts. These results would be of great help to elucidate the mechanisms of protective role of AITC on FMT. AITC may be a prospect agent for airway remodeling which are hallmarks of chronic respiratory diseases such as asthma, COPD, and IPF.

\section{Supplementary Information}

The online version contains supplementary material available at https://doi. org/10.1186/s12931-021-01636-9.

Additional file 1: Figure S1. Effect of TGF- $\beta 1$ stimulation after different time points on a-SMA and Col1A1. Cells were stimulated with TGF- $\beta 1$ ( $5 \mathrm{ng} / \mathrm{mL}$ ) and after different endpoints $(24,48,72 \mathrm{~h}$ ) RNA samples were isolated for qPCR analysis. Relative gene expressions of a-SMA and Col1A1 were already upregulated after $24 \mathrm{~h}$ as well as after 48 and $72 \mathrm{~h}\left({ }^{*} P<0.05\right)$. $\mathrm{N}=4$. Figure S2. Effect of AITC and TRPA1 antagonist HC-030031 on calcium response after TGF- $\beta 1$ stimulation. Calcium imaging analysis was performed in TGF- $\beta 1$-treated human lung fibroblasts. AITC exhibited significant calcium influx with $\mathrm{EC}_{50}$ of $2.7-3.6 \mu \mathrm{M}$ comparable to untreated in the fibroblasts treated with TGF- $\beta 1$. HC-030031 significantly inhibited calcium response ( $\left.{ }^{*} P<0.05\right)$. Table $\mathbf{S} 1$. List of primers used for $q P C R$.

\section{Abbreviations}

TRPA1: Transient receptor potential ankyrin 1; AITC: Allyl isothiocyanate; ERK: Extracellular signal-regulated kinase; MAPK: Mitogen-activated protein kinase; NRF2: Nuclear factor erythroid 2-related factor 2; HO-1: Heme oxygenase-1; a-SMA: Alpha-smooth muscle actin; Col1A1: Collagen type 1 alpha 1 chain; TIMP1: Tissue inhibitor matrix metalloproteinase 1; MMP9: Matrix metalloprotease 9; TGF- $\beta$ : Transforming growth factor beta; TNF-a: Tumor necrosis factor-a; FMT: Fibroblasts-to-myofibroblasts transition.

\section{Acknowledgments \\ None.}

\section{Authors' contributions}

$J Y$ and TU performed experiments, analyzed data, wrote the manuscript; NT, $\mathrm{KF}, \mathrm{SF}, \mathrm{TU}, \mathrm{TT}, \mathrm{HO}, \mathrm{KM}, \mathrm{Yl}$, TO discussed and supervised the study; YK contributed to the design of work, drafted and revised the manuscript; SU, AK supervised. All authors read and approved the final manuscript.

\section{Funding}

This study is supported in part by research grants from Sanofi Aventis Corporation and GlaxoSmithKline pharmaceutical company (GSK).

\section{Availability of data and materials}

The datasets used and/or analyzed during the current study are available from the corresponding author on reasonable request.

\section{Competing interests}

$J Y, T U, N T, T U, T T, Y I$ and SU have no relevant disclosures. YK reports research grants from Sanofi Aventis for the submitted work, and grants from Novartis Pharma, MSD and Kyowa-Kirin corporations outside the submitted work. KF reports a research grant from GSK for the submitted work, and a grant from Novartis Pharma outside the submitted work. SF reports personal fees from AstraZeneca, personal fees from Eli Lilly Japan outside the submitted work. $\mathrm{HO}$ reports research grant from Boehringer Ingelheim outside the submitted work. KM reports personal fees from Pfizer and Chugai Pharmaceutical outside the submitted work. TO reports personal fees from AstraZeneca, Eli Lilly Japan, Taiho Pharmaceutical, Pfizer, Chugai Pharmaceutical, MSD, Daiichi Sankyo, and Asahi Kasei Pharma, and research grants and personal fees from Kyowa Hakko Kirin, Boehringer Ingelheim, Ono Pharmaceutical, and Novaltis outside the submitted work. AN reports personal fees from Astellas, AstraZeneca, Kyorin, GSK, MSD, Shionogi, Bayer, Sanofi, Taiho and Boehringer Ingelheim, and research grants from Astellas, Kyorin, Boehringer Ingelheim, Novartis, MSD, Daiichi Sankyo, Taiho, Teijin, Ono, Takeda, Sanofi Pharmaceutical outside the submitted work.

\section{Author details}

${ }^{1}$ Department of Respiratory Medicine, Allergy and Clinical Immunology, Nagoya City University Graduate School of Medical Sciences, 1 Kawasumi, Mizuho-cho, Mizuho-ku, Nagoya 467-8601, Japan. ${ }^{2}$ Department of Anatomy and Neuroscience, Nagoya City University Graduate School of Medical Sciences, Aichi, Japan. 
Received: 21 September 2020 Accepted: 24 January 2021

Published online: 12 February 2021

\section{References}

1. Labaki WW, Han MK. Chronic respiratory diseases: a global view. Lancet Respir Med. 2020;8(6):531-3. https://doi.org/10.1016/S2213 -2600(20)30157-0.

2. Global Strategy for Asthma Management and Prevention. Updated 2020. https://ginasthma.org/wp-content/uploads/2020/06/GINA-2020-repor t_20_06_04-1-wms.pdf)

3. Global Strategy for the Diagnosis, Management, and Prevention of Chronic Obstructive Pulmonary Disease 2020 REPORT. https://goldc opd.org/wp-content/uploads/2019/12/GOLD-2020-FINAL-ver1.2-03Dec 19_WMV.pdf

4. Raghu G, Remy-Jardin M, Myers JL, Richeldi L, Ryerson CJ, Lederer DJ, Behr J, Cottin V, Danoff SK, Morell F, Flaherty KR, Wells A, Martinez FJ, Azuma A, Bice TJ, Bouros D, Brown KK, Collard HR, Duggal A, Galvin L, Inoue Y, Jenkins RG, Johkoh T, Kazerooni EA, Kitaichi M, Knight SL, Mansour G, Nicholson AG, Pipavath SNJ, Buendía-Roldán I, Selman M, Travis WD, Walsh S, Wilson KC; American Thoracic Society, European Respiratory Society, Japanese Respiratory Society, and Latin American Thoracic Society. Diagnosis of Idiopathic Pulmonary Fibrosis. An Official ATS/ERS/JRS/ALAT Clinical Practice Guideline. Am J Respir Crit Care Med. 2018;198(5):e44-e68. doi: https://doi.org/10.1164/rccm.201807-1255ST.

5. Cosío BG, Dacal D, de Llano L. Asthma-COPD overlap: identification and optimal treatment. Ther Adv Respir Dis. 2018. https://doi. org/10.1177/1753466618805662.

6. Somogyi V, Chaudhuri N, Torrisi SE, Kahn N, Müller V, Kreuter M. The therapy of idiopathic pulmonary fibrosis: what is next? Eur Respir Rev. 2019;28(153):190021. https://doi.org/10.1183/16000617.0021-2019.

7. Michalik M, Wójcik-Pszczoła K, Paw M, Wnuk D, Koczurkiewicz P, Sanak M, Pękala E, Madeja Z. Fibroblast-to-myofibroblast transition in bronchial asthma. Cell Mol Life Sci. 2018;75(21):3943-61. https://doi.org/10.1007/ s00018-018-2899-4

8. Pini L, Pinelli V, Modina D, Bezzi M, Tiberio L, Tantucci C. Central airways remodeling in COPD patients. Int J Chron Obstruct Pulmon Dis. 2014;1(9):927-32. https://doi.org/10.2147/COPD.S52478.

9. Tomos IP, Tzouvelekis A, Aidinis V, Manali ED, Bouros E, Bouros D, Papiris SA. Extracellular matrix remodeling in idiopathic pulmonary fibrosis. It is the 'bed' that counts and not 'the sleepers'. Expert Rev Respir Med. 2017;11(4):299-309. doi: https://doi.org/10.1080/17476348.2017.1300533. (Epub 2017 Mar 8).

10. Larsen K, Tufvesson E, Malmström J, Mörgelin M, Wildt M, Andersson A, Lindström A, Malmström A, Löfdahl CG, Marko-Varga G, Bjermer L, Westergren-Thorsson G. Presence of activated mobile fibroblasts in bronchoalveolar lavage from patients with mild asthma. Am J Respir Crit Care Med. 2004;170(10):1049-56. https://doi.org/10.1164/rccm.200404-5070C.

11. Upagupta C, Shimbori C, Alsilmi R, Kolb M. Matrix abnormalities in pulmonary fibrosis. Eur Respir Rev. 2018;27(148):180033. https://doi. org/10.1183/16000617.0033-2018

12. Karvonen HM, Lehtonen ST, Harju T, Sormunen RT, Lappi-Blanco E, Mäkinen JM, Laitakari K, Johnson S, Kaarteenaho RL. Myofibroblast expression in airways and alveoli is affected by smoking and COPD. Respir Res. 2013;14(1):84. https://doi.org/10.1186/1465-9921-14-84.

13. Walker EJ, Heydet D, Veldre T, Ghildyal R. Transcriptomic changes during TGF- $\beta$-mediated differentiation of airway fibroblasts to myofibroblasts. Sci Rep. 2019;9:20377. https://doi.org/10.1038/s41598-019-56955-1.

14. Hu B, Wu Z, Phan SH. Smad3 mediates transforming growth factor-betainduced alpha-smooth muscle actin expression. Am J Respir Cell Mol Biol. 2003:29(3 Pt 1):397-404. https://doi.org/10.1165/rcmb.2003-0063OC.

15. Al-Alawi M, Hassan T, Chotirmall SH. Transforming growth factor $\beta$ and severe asthma: a perfect storm. Respir Med. 2014;108(10):1409-23. https ://doi.org/10.1016/j.rmed.2014.08.008.

16. Schruf E, Schroeder V, Kuttruff CA, Weigle S, Krell M, Benz M, Bretschneider T, Holweg A, Schuler M, Frick M, Nicklin P, Garnett JP, Sobotta MC. Human lung fibroblast-to-myofibroblast transformation is not driven by an LDH5-dependent metabolic shift towards aerobic glycolysis. Respir Res. 2019;20(1):87. https://doi.org/10.1186/s12931-019-1058-2.
17. Cheresh P, Kim SJ, Tulasiram S, Kamp DW. Oxidative stress and pulmonary fibrosis. Biochim Biophys Acta. 2013;1832(7):1028-40. https://doi. org/10.1016/j.bbadis.2012.11.021.

18. Li M, Keenan CR, Lopez-Campos G, Mangum JE, Chen Q, Prodanovic D, Xia YC, Langenbach SY, Harris T, Hofferek V, Reid GE, Stewart AG. A Non-canonical Pathway with Potential for Safer Modulation of Transforming Growth Factor- $\beta 1$ in Steroid-Resistant Airway Diseases. iScience. 2019;12:232-46. https://doi.org/10.1016/j.isci.2019.01.023.

19. Yap JMG, Ueda T, Takeda N, Fukumitsu K, Fukuda S, Uemura T, Tajiri T, Ohkubo H, Maeno K, Ito Y, Kanemitsu Y, Niimi A. An inflammatory stimulus sensitizes TRPA1 channel to increase cytokine release in human lung fibroblasts. Cytokine. 2020;129:155027. https://doi.org/10.1016/j. cyto.2020.155027

20. Kurahara LH, Hiraishi K, Hu Y, Koga K, Onitsuka M, Doi M, Aoyagi K, Takedatsu H, Kojima D, Fujihara Y, Jian Y, Inoue R. Activation of Myofibroblast TRPA 1 by Steroids and Pirfenidone Ameliorates Fibrosis in Experimental Crohn's Disease. Cell Mol Gastroenterol Hepatol. 2017;5(3):299-318. https //doi.org/10.1016/j.jcmgh.2017.12.005.

21. Negmadjanov U, Godic Z, Rizvi F, Emelyanova L, Ross G, Richards J, Holmuhamedov EL, Jahangir A. TGF-B1-mediated differentiation of fibroblasts is associated with increased mitochondrial content and celIular respiration. PLoS ONE. 2015;10(4):e0123046. https://doi.org/10.1371/ journal.pone.0123046

22. Sun Q, Wu Y, Zhao F, Wang J. Maresin 1 inhibits transforming growth factor- $\beta 1$-induced proliferation, migration and differentiation in human lung fibroblasts. Mol Med Rep. 2017;16(2):1523-9. https://doi. org/10.3892/mmr.2017.6711.

23. Salem S, Harris T, Mok JS, Li MY, Keenan CR, Schuliga MJ, Stewart AG. Transforming growth factor- $\beta$ impairs glucocorticoid activity in the A549 lung adenocarcinoma cell line. Br J Pharmacol. 2012;166(7):2036-48. https://doi.org/10.1111/j.1476-5381.2012.01885.x.

24. Dolivo DM, Larson SA, Dominko T. Crosstalk between mitogen-activated protein kinase inhibitors and transforming growth factor- $\beta$ signaling results in variable activation of human dermal fibroblasts. Int J Mol Med. 2019;43(1):325-35. https://doi.org/10.3892/ijmm.2018.3949.

25. Javelaud D, Mauviel A. Crosstalk mechanisms between the mitogenactivated protein kinase pathways and Smad signaling downstream of TGF-beta: implications for carcinogenesis. Oncogene. 2005;24(37):574250. https://doi.org/10.1038/sj.onc.1208928.

26. Fredenburgh LE, Perrella MA, Mitsialis SA. The role of heme oxygenase-1 in pulmonary disease. Am J Respir Cell Mol Biol. 2007;36(2):158-65. https ://doi.org/10.1165/rcmb.2006-0331TR.

27. Lin CC, Hsiao LD, Cho RL, Yang CM. Carbon monoxide releasing molecule-2-upregulated ros-dependent heme oxygenase-1 axis suppresses lipopolysaccharide-induced airway inflammation. Int J Mol Sci. 2019;20(13):3157. https://doi.org/10.3390/ijms20133157.

28. Zheng L, Zhou Z, Lin L, Alber S, Watkins S, Kaminski N, Choi AM, Morse D. Carbon monoxide modulates alpha-smooth muscle actin and small proline rich-1a expression in fibrosis. Am J Respir Cell Mol Biol. 2009;41(1):8592. https://doi.org/10.1165/rcmb.2007-04010C.

29. Nakamura T, Matsushima M, Hayashi Y, Shibasaki M, Imaizumi K, Hashimoto N, Shimokata K, Hasegawa Y, Kawabe T. Attenuation of transforming growth factor- $\beta$-stimulated collagen production in fibroblasts by quercetin-induced heme oxygenase-1. Am J Respir Cell Mol Biol. 2011;44(5):614-20. https://doi.org/10.1165/rcmb.2010-03380C.

30. Keenan CR, Mok JS, Harris T, Xia Y, Salem S, Stewart AG. Bronchial epithelial cells are rendered insensitive to glucocorticoid transactivation by transforming growth factor- $\beta 1$. Respir Res. 2014;15(1):55. https://doi. org/10.1186/1465-9921-15-55.

31. Lee MJ, Pickering RT, Shibad V, Wu Y, Karastergiou K, Jager M, Layne MD, Fried SK. Impaired glucocorticoid suppression of TGF $\beta$ signaling in human omental adipose tissues limits adipogenesis and may promote fibrosis. Diabetes. 2019;68(3):587-97. https://doi.org/10.2337/db18-0955.

32. Barnes PJ. Mechanisms and resistance in glucocorticoid control of inflammation. J Steroid Biochem Mol Biol. 2010;120(2-3):76-85. https://doi. org/10.1016/j.jsbmb.2010.02.018.

33. Virk H, Mccarthy J, Castells E, Feghali-Bostwick C, Bowman V, Amrani Y, Cousins D, Roach K. TGFß1-induces resistance to apoptosis in human lung myofibroblasts via TRPA1 downregulation [abstract]. Eur Respir J. 2019;54(suppl 63):PA5378. https://doi.org/10.1183/13993003.congress2019.PA5378. 
34. Virk H, Castells E, Bowman V, Feghali-Bostwick C, Amrani Y, Bradding P, Roach K. TRPA1 ion channel expression in human lung myofibroblasts [abstract]. Eur Respir J. 2019;54(suppl 63):PA1288. https://doi. org/10.1183/13993003.congress-2019.PA1288.

35. Kistner K, Siklosi N, Babes A, Khalil M, Selescu T, Zimmermann K, Wirtz S, Becker C, Neurath M, Reeh P, Engel MA. Systemic desensitization through TRPA1 channels by capsazepine and mustard oil - a novel strategy against inflammation and pain. Sci Rep. 2016;6:28621. https://doi.org/10.1038/ srep28621.

36. Chen J, Hackos DH. TRPA1 as a drug target—promise and challenges. Naunyn-Schmiedeberg's Arch Pharmacol. 2015;388:451-63. https://doi. org/10.1007/s00210-015-1088-3

37. Radresaa, O., Dahllöfb, H., Nymanb, E., Noltingb, A., Alberta, JS., Raboisson, P. Roles of TRPA1 in pain pathophysiology and implications for the development of a new class of analgesic drugs. Open Pain J, 2013, 6(Suppl M14): 137-153. DOI: https://doi.org/10.2174/1876386301306010137

38. Mori N, Kawabata F, Matsumura S, Hosokawa H, Kobayashi S, Inoue K, Fushiki T. Intragastric administration of allyl isothiocyanate increases carbohydrate oxidation via TRPV1 but not TRPA1 in mice. Am J Physiol Regul Integr Comp Physiol. 2011;300(6):R1494-505. https://doi.org/10.1152/ ajpregu.00645.2009.

39. Capasso R, Aviello G, Romano B, Borrelli F, De Petrocellis L, Di Marzo V, Izzo AA. Modulation of mouse gastrointestinal motility by allyl isothiocyanate, a constituent of cruciferous vegetables (Brassicaceae): evidence for TRPA1-independent effects. Br J Pharmacol. 2012;165(6):1966-77. https:// doi.org/10.1111/j.1476-5381.2011.01703.x

40. Gees M, Alpizar YA, Boonen B, Sanchez A, Everaerts W, Segal A, Xue F, Janssens A, Owsianik G, Nilius B, Voets T, Talavera K. Mechanisms of transient receptor potential vanilloid 1 activation and sensitization by allyl isothiocyanate. Mol Pharmacol. 2013;84(3):325-34. https://doi. org/10.1124/mol.113.085548.

41. Ernst IM, Wagner AE, Schuemann C, Storm N, Höppner W, Döring F, Stocker A, Rimbach G. Allyl-, butyl- and phenylethyl-isothiocyanate activate Nrf2 in cultured fibroblasts. Pharmacol Res. 2011;63(3):233-40. https ://doi.org/10.1016/j.phrs.2010.11.005.

42. Zhou Y, Xu X, Wu J, Xu L, Zhang M, Li Z, Wang D. Allyl isothiocyanate treatment alleviates chronic obstructive pulmonary disease through the Nrf2-Notch1 signaling and upregulation of MRP1. Life Sci. 2020;15(243):117291. https://doi.org/10.1016/j.lfs.2020.117291.

43. Spiess PC, Kasahara D, Habibovic A, Hristova M, Randall MJ, Poynter $M E$, van der Vliet A. Acrolein exposure suppresses antigen-induced pulmonary inflammation. Respir Res. 2013;14(1):107. https://doi. org/10.1186/1465-9921-14-107.

44. Yan B, Ma Z, Shi S, Hu Y, Ma T, Rong G, Yang J. Sulforaphane prevents bleomycin-induced pulmonary fibrosis in mice by inhibiting oxidative stress via nuclear factor erythroid 2-related factor-2 activation. Mol Med Rep. 2017;15(6):4005-14. https://doi.org/10.3892/mmr.2017.6546.
45. Moore WC, Bleecker ER, Curran-Everett D, Erzurum SC, Ameredes BT, Bacharier L, Calhoun WJ, Castro M, Chung KF, Clark MP, Dweik RA, Fitzpatrick AM, Gaston B, Hew M, Hussain I, Jarjour NN, Israel E, Levy BD, Murphy JR, Peters SP, Teague WG, Meyers DA, Busse WW, Wenzel SE; National Heart, Lung, Blood Institute's Severe Asthma Research Program. Characterization of the severe asthma phenotype by the National Heart, Lung, and Blood Institute's Severe Asthma Research Program. J Allergy Clin Immunol. 2007;119(2):405-13. doi: https://doi.org/10.1016/j. jaci.2006.11.639.

46. He Y, Shi J, Nguyen QT, You E, Liu H, Ren X, Wu Z, Li J, Qiu W, Khoo SK, Yang T, Yi W, Sun F, Xi Z, Huang X, Melcher K, Min B, Xu HE. Development of highly potent glucocorticoids for steroid-resistant severe asthma. Proc Natl Acad Sci U S A. 2019;116(14):6932-7. https://doi.org/10.1073/ pnas.1816734116.

47. Munson JC, Kreider M, Chen Z, Christie JD, Kimmel SE. Factors associated with the use of corticosteroids in the initial management of idiopathic pulmonary fibrosis. Pharmacoepidemiol Drug Saf. 2010;19(7):756-62. https://doi.org/10.1002/pds.1959.

48. Barnes PJ. Corticosteroid resistance in patients with asthma and chronic obstructive pulmonary disease. J Allergy Clin Immunol. 2013;131(3):63645. https://doi.org/10.1016/j.jaci.2012.12.1564.

49. Sakurai H, Morishima Y, Ishii Y, Yoshida K, Nakajima M, Tsunoda Y, Hayashi SY, Kiwamoto T, Matsuno Y, Kawaguchi M, Yamamoto M, Hizawa N. Sulforaphane ameliorates steroid insensitivity through an Nrf2dependent pathway in cigarette smoke-exposed asthmatic mice. Free Radic Biol Med. 2018;129:473-85. https://doi.org/10.1016/j.freeradbio med.2018.10.400.

50. Al-Harbi NO, Nadeem A, Ahmad SF, AlThagfan SS, Alqinyah M, Alqahtani F, Ibrahim KE, Al-Harbi MM. Sulforaphane treatment reverses corticosteroid resistance in a mixed granulocytic mouse model of asthma by upregulation of antioxidants and attenuation of Th17 immune responses in the airways. Eur J Pharmacol. 2019;15(855):276-84. https://doi.org/10.1016/j. ejphar.2019.05.026.

51. Adenuga D, Caito S, Yao H, Sundar IK, Hwang JW, Chung S, Rahman I. Nrf2 deficiency influences susceptibility to steroid resistance via HDAC2 reduction. Biochem Biophys Res Commun. 2010;403(3-4):452-6. https:// doi.org/10.1016/j.bbrc.2010.11.054.

52. Mei D, Tan WSD, Wong WSF. Pharmacological strategies to regain steroid sensitivity in severe asthma and COPD. Curr Opin Pharmacol. 2019;46:7381. https://doi.org/10.1016/j.coph.2019.04.010.

\section{Publisher's Note}

Springer Nature remains neutral with regard to jurisdictional claims in published maps and institutional affiliations.

Ready to submit your research? Choose BMC and benefit from

- fast, convenient online submission

- thorough peer review by experienced researchers in your field

- rapid publication on acceptance

- support for research data, including large and complex data types

- gold Open Access which fosters wider collaboration and increased citations

- maximum visibility for your research: over 100M website views per year

At BMC, research is always in progress.

Learn more biomedcentral.com/submissions 